\title{
WOLNY RYNEK A BEZPIECZEŃSTWO ŻYWNOŚCI W EPOCE GLOBALIZACJI
}

\author{
Stanisław Kowalczyk \\ Instytut Rynków i Konkurencji, Szkoła Główna Handlowa w Warszawie \\ Dyrektor Instytutu: dr hab. Roman Sobiecki, prof. SGH
}

\begin{abstract}
Słowa kluczowe: bezpieczeństwo żywności, interwencjonizm, fałszowanie żywności, prawo żywnościowe, kontrole żywności, krótkie łańcuchy dostaw, ruchy konsumenckie

Key words: food safety, interventionism, food adulteration, food law, food controls, short supply chains, consumer movements

S y n o p s i s. Podjęto próbę identyfikacji potencjalnych zagrożeń bezpieczeństwa żywności wynikających z procesu globalizacji oraz bezpośrednio związanej z nią skrajnej liberalizacji stosunków gospodarczych na poziomie międzynarodowym oraz wskazanie niezbędnych działań zaradczych w zakresie ochrony statusu bezpieczeństwa żywności. Analizie poddano współczesny status bezpieczeństwa żywności oraz skalę występujących fałszerstw żywnościowych na świecie. Do działań zaradczych zaliczono ustanowienie globalnego prawa żywnościowego, podejmowanie inicjatyw kontrolnych żywności na szczeblu ponadkrajowym, promocję krótkich łańcuchów dostaw, wreszcie edukację konsumentów i wzmocnienie ruchów konsumenckich.
\end{abstract}

\section{WPROWADZENIE}

Jednym z elementarnych obszarów dyskusyjnych w naukach ekonomicznych jest kwestia ile rynku, a ile państwa. Jest to problem prawie tak stary, jak istota państwa $\mathrm{i}$ konstrukcja rynku. I - co warto zaznaczyć - dyskurs prowadzony jest tu nie tylko przez skrajne nurty ekonomii, jak marksizm i liberalizm, lecz pojawia się cyklicznie w wielu szkołach ekonomicznych. Ta cykliczność każe zwrócić uwagę nie tyle na zainteresowanie różnych nurtów ekonomii tym zagadnieniem, ile raczej na sytuację, która kształtuje się w rzeczywistości gospodarczej, a także politycznej i społecznej. Inaczej, czy przeważa zapotrzebowanie na niczym nieskrępowane relacje międzyludzkie w zakresie wymiany towarów, czy też pojawia się silniejsze zapotrzebowanie na ingerencję instytucji państwa w ten obszar. Ingerencję wynikającą z braku akceptacji przez znaczącą część społeczeństwa właśnie dla tych nieskrępowanych relacji gospodarczych.

Celem opracowania jest identyfikacja potencjalnych zagrożeń dla bezpieczeństwa żywności, wynikających z procesu globalizacji oraz związanej z nią skrajnej liberalizacji stosunków gospodarczych na poziomie międzynarodowym oraz próba wskazania działań zaradczych w zakresie ochrony statusu bezpieczeństwa żywności. 


\section{PARADOKS: WOLNOŚĆ GOSPODARCZA VERSUS INTERWENCJA PAŃSTWA}

Ten swoisty paradoks wolność gospodarcza versus interwencja państwa, podejmował i próbował wyjaśnić już w końcu XVIII w. Adam Smith w swoim fundamentalnym dziele Badania nad natura i przyczynami bogactwa narodów [1776]. A. Smith pisał między innymi, że naturalny konflikt społeczny powstaje między jednostkami, ponieważ efekt pracy z natury powinien należeć do wykonawcy, lecz musi on dzielić się nim z właścicielem zasobów, który go zatrudnia [Smith 1776]. To, co ostatecznie otrzymuje, zależy od wielu rzeczy, lecz najmniej od samego robotnika. Płaca robotnika i zyski kapitalisty zależą np. od siły manufaktur i siły państwa oraz bogactwa społeczeństwa. Z reguły wolność (u A. Smitha jest to „wolność handlowa”) jest mniej ryzykowna w dużych, bogatych państwach, gdzie wzrost jest pewniejszy, a możliwe zaburzenia podaży niższe [Smith 1776]. Siła państwa przesądza zatem o pozycji jego organów w sferze społecznej i gospodarczej. Jednak A. Smith był daleki od popierania zaangażowania państwa w gospodarkę, a przynajmniej gdy nie służyło to Wielkiej Brytanii. Protekcjonizmu brytyjskiego nie atakował. Amerykanom odradzał protekcjonizmu własnego przemysłu, albowiem zamiast przyspieszyć, może to opóźnić postęp ich kraju na drodze do bogactwa [Smith 1776, s. 367].

Jak zatem historycznie kształtowała się relacja tych dwóch fenomenów, tj. ile było w przeszłości wolności gospodarczej (liberalizmu), a ile ingerencji państwa (interwencjonizmu)? Okazuje się, że przeszłość wykazała na tym polu wyjątkową złożoność. Jej główne etapy były następujące:

- $\quad$ silny protekcjonizm w Anglii: od końca XV w. do połowy XVIII w. (początek to okres panowania króla Henryka VII i Henryka VIII, chociaż pierwsze działania protekcjonistyczne wystąpiły już na przełomie XIII i XIV w.); protekcjonizm dotyczył pierwotnie przetwórstwa wełny i skierowany był przeciwko Niderlandom, potem także innych gałęzi i dotyczył USA i kolonii brytyjskich; Wielka Brytania była krajem silnego protekcjonizmu do połowy XIX w., czyli momentu, gdy zbudowała swój przemysł; największa liberalizacja od lat 60. XIX w. do Wielkiego Kryzysu lat 30. XX w.

- silny protekcjonizm w USA: od początku XIX w. do połowy XX w. (twórca Alexader Hamilton 1755/57-1804),

- okres względnego liberalizmu gospodarczego w większości krajów (poza Wielką Brytanią): II połowa XVIII w. - przełom II/III dekady XIX w. (początki industrializacji),

- liberalizm gospodarczy w teorii i interwencjonizm w praktyce: przełom II/III dekady XIX w. - przełom XIX/XX w.,

- dominacja liberalizmu gospodarczego - przełom XIX/XX w. - lata 30. XX w.,

- okres interwencjonizmu gospodarczego - lata 30. XX w. - koniec lat 70. XX w. (także w krajach rozwijających się, dawnych koloniach, w Chinach do lat 90 . XX w., w Indiach nawet aktualnie - cła $25 \%$.),

- dominacja liberalizmu gospodarczego: koniec lat 70. XX w. - pierwsza dekada XXI w.,

- brak zdecydowanej dominacji z narastającym przekonaniem o potrzebie wzrostu znaczenia interwencjonizmu i roli państwa - przełom I/II dekady XXI w. (początek nowego cyklu paradoksu wolność gospodarcza versus ingerencja państwa?).

Ogólne doświadczenia z historii są zatem następujące: (i) przez stulecia w większości państw przeważała polityka protekcjonizmu własnej gospodarki nad liberalizmem, (ii) poszczególne kraje głosiły potrzebę liberalizacji wymiany towarowej dopiero wówczas, gdy zbudowały silną własną gospodarkę (przykład Wielkiej Brytanii w II połowie XIX w.), (iii) jednak nawet deklaratywnemu opowiadaniu się za liberalizacją stosunków go- 
spodarczych często towarzyszył przemilczany protekcjonizm (przykład USA w II połowie XX w.), (iv) z prawdziwą liberalizacją stosunków gospodarczych i wymiany towarowej, jakiej nie znała przeszłość, mamy do czynienia dopiero od lat 80 . XX w. I jest ona raczej konsekwencją gospodarczej ewolucji świata, a nie przyczyną tej ewolucji. Podstawowa przyczyna wynika bowiem przede wszystkim z globalizacji oraz znacznej marginalizacji siły państwa w stosunku do rynkowej siły korporacji transnarodowych. A zatem jak twierdzi Ha-Joon Chang wolny handel nie działa [Chang 2016, s. 116], a liberalizacja niekoniecznie przynosi ogólne korzyści. Dowiódł tego także pierwszy kryzys ery globalnej, czyli kryzys lat 2007-2009/10. Jakie zatem wnioski wynikają z tego dla gospodarki, w tym przede wszystkim sektora agrobiznesu i bezpieczeństwa żywności?

\section{KONSEKWENCJE GLOBALIZACJI}

Świat zmienia się ciągle, lecz w tym stałym procesie są okresy wyższej i niższej dynamiki zachodzących zmian. Jeden $\mathrm{z}$ takich okresów, który odegrał znaczącą rolę $\mathrm{w}$ ukształtowaniu współczesnej struktury świata, rozpoczął się na przełomie lat 70. i 80. XX w. za sprawą koncepcji gospodarczych wprowadzonych praktycznie w tym samym czasie w Wielkiej Brytanii przez Margaret Thatcher (premier w latach 1979-1990) i w USA, przez Ronalda Reagana (prezydent w latach 1981-1989). Koncepcji polegającej na wycofywaniu się państwa z życia publicznego, przede wszystkim gospodarczego, na rzecz własności prywatnej. Rolę państwa w wielu dziedzinach przejęły firmy prywatne-korporacje, szybko przyjmujące postać firm transnarodowych.

Liberalizacja stosunków gospodarczych oraz powstanie struktur wspierających ten proces, czyli powołanie w 1994 r. Światowej Organizacji Handlu (WTO), zwielokrotniły dynamikę międzynarodowych przepływów towarowych. Łączny eksport światowy w latach 1948-1963, a więc w ciągu 15 lat, wzrósł z 59 mld USD do 157 mld USD, czyli o niecałe 100 mld USD. Znaczącego rozwoju wymiany handlowej nie było także w kolejnej dekadzie. Niewątpliwie był to, z jednej strony, efekt tzw. zimnej wojny pomiędzy głównymi blokami politycznymi i gospodarczymi i z drugiej, niesprzyjających wymianie handlowej warunków światowych (ograniczenia w przepływie kapitału, bariery celne, embarga towarowe). Początki ożywienia handlowego odnotowano dopiero w latach 70. i 80. XX w., a prawdziwy boom i ekspansja handlowa stały się faktem po 1990 r. O ile w latach 1983-1993 światowy eksport zwiększył się o 1850 mld USD, o tyle w kolejnym okresie 1993-2003 już o prawie 3700 mld USD, a w latach 2003-2016 o kolejne prawie 8100 mld USD, do kwoty 15464 mld USD [WTO 2017]. W latach 1948-2016 światowy eksport zwiększył się ponad 260 razy, przy czym w latach 1948-1973 niecałe 10 razy i w latach 1973-2016 - ponad 27 razy. Stanowi to wymowną ilustrację wpływu globalizacji na rozwój światowej wymiany handlowej.

W dynamice tej swój udział miał także handel rolny. Tylko w latach 2006-2016 średnia roczna stopa wzrostu obrotów tej grupy produktów wyniosła 5,3\%, podczas gdy produktów przetworzonych 3,2\%, a paliw i kopalin $-1 \%$. W następstwie tego udział handlu rolnego w światowych obrotach towarowych zwiększył się z 8,2\% w 2006 r. do 10,5\% w 2016 r. [WTO 2017].

Poza liberalizacją sfery gospodarczej oraz wymiany handlowej, drugim zasadniczym czynnikiem napędowym zmian ostatnich czterech dekad - określanych jako globalizacja - była głęboka redukcja kosztów transportu i komunikacji [Kowalczyk 2010]. Przykładowo koszt transportu morskiego zmniejszył się w latach 1920-2015 o 90\%, 3-minutowej rozmowy telefonicznej pomiędzy Nowym Jorkiem a Londynem z 293 USD w 1931 r. 
praktycznie do zera (przy wykorzystaniu połączeń internetowych), połączeń lotniczych w latach 1946-2015 o 90\%, a cena 1 GB ze 193 tys. USD w 1980 r. do 7 centów w 2010 r. [The Geography of Transport Systems 2017]. Tym, co uruchomiło powyższe procesy, były samoloty nowych generacji (Boeing), światłowody, wydajne komputery, wreszcie Internet.

Redukcja kosztów przemieszczania i komunikowania się uruchomiła wielokierunkowe i często nieoczekiwane zmiany w strukturze gospodarki światowej. Nastąpiła przede wszystkim redukcja lokalnej renty monopolowej [Gersbach, Schmutzler 2000]. Producent lokalny stanął wobec konkurencji potencjalnie nieograniczonej liczby firm wytwarzających taki sam produkt. W ślad za tym postępują zmiany, które jednak już nie są takie oczywiste. Dotyczy to w pierwszej kolejności zmiany lokalizacji firm. Stanowisko nauki w tej sprawie ma charakter dychotomiczny. Jedni twierdzą, że redukcja kosztów transportu będzie prowadziła do koncentracji firm, ponieważ będzie opłaciło się dostarczać towary nawet na duże odległości i jednocześnie korzystać z efektu skali - jednego miejsca wytwarzania dla wielu rynków [Krugman 1991]. Inni uważają, że zjawisko niskich kosztów transportu może jednak przeciwdziałać koncentracji produkcji na rzecz jej lokalizacji blisko rynku popytu dzięki wykorzystaniu łatwo dostępnej (właśnie dzięki niskim kosztom transportu i komunikacji) wiedzy i doświadczenia centrali oraz poszukiwaniu dodatkowych przewag konkurencyjnych na miejscu [Gersbach, Schmutzler 2000]. Rzeczywistość zdaje się jednak jeszcze bardziej skomplikowana i przyjmuje obydwa modele, tj. koncentracji i dekoncentracji w zależności od rodzaju produktu, rynku, warunków środowiskowych i wielu innych uwarunkowań. Natomiast prawdą pozostaje zwiększony przepływ towarów w relacjach międzynarodowych i regionalnych.

Poza omówionymi konsekwencjami redukcji kosztów transportu i komunikowania się, występują także inne na pozór mniej oczywiste procesy. Jednym z nich są migracje (stałe i czasowe) z terenów biedniejszych do regionów bogatszych i aglomeracji. Widoczne jest to na przykładzie migracji wewnętrznych we Włoszech z biednego Południa w kierunku bogatej Północy [The International Bank for Reconstruction and Development/The World Bank 2009]. Oczekiwano przenoszenia miejsc pracy właśnie na tereny o wyższym wskaźniku bezrobocia i tym samym możliwych niższych kosztów płac. Tak się jednak (przynajmniej w wymiarze masowym) nie stało. To siła robocza podąża za miejscem pracy. Ponadto szybko rozwijający się handel dotyczy w głównym stopniu krajów sąsiadujących i tych najbliższych. Można było oczekiwać raczej transakcji na duże odległości. Takie także występują i w wyjątkowo znaczącym stopniu dotyczy to żywności, lecz transport „sąsiedzki” stanowi współcześnie znaczącą część światowych obrotów. Tłumaczone jest to z reguły podobieństwami w zakresie popytu, oczekiwań konsumentów oraz większego przekonania do producentów „zza miedzy” niż z odległych części świata.

Odchodzenie w ostatnich dekadach od polityki interwencjonizmu oraz redukcja podstawowych funkcji państwa na rzecz idei wolnego samoregulującego się rynku ma istotny wpływ na system gospodarczy i społeczny, a w tym na produkcję oraz bezpieczeństwo żywności. I dotyczy to zarówno wymiaru krajowego, jak i globalnego. W coraz większym bowiem stopniu o warunkach rynkowych przesądzają decyzje korporacji, a w coraz mniejszym decyzje państw czy organizacji międzynarodowych. W odniesieniu do agrobiznesu i produkcji żywności oznacza to, że za światową podaż odpowiada coraz mniej coraz większych globalnych korporacji spożywczych. A te, jak wiadomo, od czasu słynnego wyroku Dodge vs. Ford Motor Co. (1919) Sądu Najwyższego stanu Michigan [Dodge v. Ford Motor Co. 1919], powinny kierować się wyłącznie interesem akcjonariuszy, a nie innymi względami, jak chociażby społecznymi, humanitarnymi czy dobrem 
i bezpieczeństwem konsumentów ${ }^{1}$. Dla konsumentów może to oznaczać pierwszeństwo interesu firmy spożywczej przed ich interesem, a to z kolei oznacza niższy poziom bezpieczeństwa żywności. Wiąże się bowiem z działaniami ze strony podmiotów rynkowych w zakresie zwiększenia ich finansowych korzyści kosztem konsumentów. Te działania to wykorzystywanie do produkcji żywności, zanieczyszczonych surowców, niższy reżim technologiczny, czy fałszowanie żywności. Działania zdecydowanie sprzeczne z koncepcją bezpieczeństwa żywności i ochrony interesów konsumentów.

\section{WSPÓŁCZESNY STAN BEZPIECZEŃSTWA ŻYWNOŚCI}

W tej sytuacji powstaje naturalne pytanie o stan, poziom bezpieczeństwa żywności we współczesnej gospodarce. To, że podlegają one istotnym zmianom, zwłaszcza w ostatnich dekadach, raczej nie ulega wątpliwości. Zmiany te dotyczą zarówno poziomu samego bezpieczeństwa żywności, w tym rosnących dla niego zagrożeń, jak i podejmowanych działań w celu utrzymania pożądanego poziomu tegoż bezpieczeństwa.

Przeprowadzone badania ponad 700 incydentów żywnościowych ${ }^{2}$, które odnotowano w latach 1828-2015 dowodzą, że przewartościowały one gospodarki poszczególnych państw, regionów i całego globu w zakresie bezpieczeństwa żywności. Najwięcej analizowanych przypadków pochodzi z XXI w. Z ogólnej liczby analizowane incydenty z pierwszej połowy XX w. to około $5 \%$, z drugiej połowy $-29 \%$ i aż około $65 \%$ to incydenty z XXI w. Warto podkreślić, że pierwsze dwa okresy (1900-1950, 1950-2000) trwały po 50 lat, natomiast ostatni tylko - 15 lat (2001-2015). W pierwszej połowie drugiej dekady XXI w. (lata 2011-2015) odnotowano średniorocznie ponaddwukrotnie więcej znaczących incydentów niż w pierwszej dekadzie bieżącego stulecia (lata 2001-2010). Warto dodać, że gdyby w drugiej połowie dekady 2011-2020 tendencja w zakresie średniej rocznej liczby incydentów żywnościowych utrzymała się na poziomie z pierwszej połowy, to wówczas w ciągu całej tej dekady liczba incydentów byłaby dwukrotnie wyższa niż w latach 2001-2010.

Analiza incydentów żywnościowych przedstawionych powyżej, ich rozkład w czasie - nawet po uwzględnieniu mniejszej dostępności informacji o incydentach z XIX w. - skłaniają do konkluzji, że mamy właśnie do czynienia z tzw. drugą falą fałszerstw (oszustw) żywnościowych na świecie. Pierwsza fala przeszła w połowie XIX w., a informacje o niej są zawartych nie tyle w raportach instytucji kontrolnych, ponieważ takich w zakresie kontroli żywności jeszcze nie było, ile w opracowaniach naukowych [Accum 1820, Hassall 1855, Normandy 1850, Mitchell 1848], informacjach prasowych oraz innych dostępnych materiałach z tego okresu.

Pierwszy okres masowego fałszowania i podrabiania żywności (także leków) odnotowano w XIX w., a więc wtedy, gdy pojawił się masowy, anonimowy klient. Fałszowanie żywności datuje się co prawda od tak dawna, od kiedy człowiek produkuje, przetwarza i sprzedaje artykuły żywnościowe. Jednak wiek XIX - jak podkreślili to Harry Cendrowski,

1 Należy dodać, że w 1968 r. Sąd Najwyższy stanu Illinois, w sprawie Shlensky vs. Wrigley, (237 NE 2d 776, Ill. App. 1968) o instalację świateł na stadionie wydał wyrok, w którym odniósł się do roli przedstawicieli zarządu firmy w równoważeniu różnych, często sprzecznych interesów akcjonariuszy, wskazując, że decyzje te przede wszystkim nie mogą być nielegalne bądź sprzeczne z prawem. Wyrok ten w orzecznictwie amerykańskim często przeciwstawia się wyrokowi w sprawie Dodge vs. Ford Motor Co. z 1919 r.

2 Incydent żywnościowy (ang. food incydent) to każde zdarzenie, które bazuje na dostępnych informacjach $\mathrm{i}$ dotyczy rzeczywistych lub potencjalnych/możliwych zagrożeń dla bezpieczeństwa i jakości żywności oraz pasz, wymagające interwencji w celu ochrony konsumentów. Por: Annual Report of Incidents 2013, Food Standards Agency, June 2014, s. 28. https://www.food.gov.uk/annual-report-incidents-2013.pdf. 
Louis W. Petro - był szczególny pod tym względem, liczba oszustw i fałszerstw żywnościowych wzrosła bowiem dramatycznie [Cendrowski, Petro 2007].

Na początku XXI w. sytuacja wcale nie przedstawia się lepiej niż w połowie XIX w., a wiele wskazuje, iż pomimo istniejących współcześnie systemów urzędowej kontroli żywności, praktycznie we wszystkich krajach świata - pomijam w tym miejscu ocenę skuteczności tych systemów kontrolnych - przedstawia się tak samo źle, a nie można wykluczyć, że i mniej korzystnie aniżeli 150 lat temu. Można wskazać wiele przykładów potwierdzających powyższą tezę. Kilka wybranych to: (i) Horsemeat scandal, czyli fałszowanie burgerów wołowych mięsem końskim na rynku europejskim, (ii) połowa francuskiego wina sprzedawana w Chinach jest zafałszowana, (iii) według brytyjskiej FDA 1/3 dań na wynos w Wielkiej Brytanii jest zafałszowana, (iv) według kontroli włoskiej służby NAS (Carabinieri) w 1/2 włoskich punktów sprzedaży żywności są mniejsze lub większe nieprawidłowości, (v) według M. Weinberga z Inscatech, amerykańskiej firmy zajmującej się bezpieczeństwem żywności oraz zwalczaniem fałszerstw żywnościowych, około 50$60 \%$ wszystkich partii żywności na świecie jest mniej lub bardziej zafałszowanych, (vi) według raportu firmy Oceana działającej na rzecz ochrony mórz i oceanów, średnio 43\% partii zimowego łososia na rynku amerykańskim jest zafałszowana (w restauracjach udział nieprawidłowo oznakowanych partii wynosi $2 / 3$ ), (vii) prawie $70 \%$ oliwy z oliwek extra virgin na rynku amerykańskim jest zafałszowane.

Nasilenie incydentów żywnościowych w końcu XX w. sygnalizowali także autorzy raportu WHO Food and health in Europe, wskazując iż od początku lat 80. XX wieku nasila się fala zachorowań w następstwie spożycia skażonej żywności. Potwierdzają to także informacje z monitoringu epidemii chorób pokarmowych amerykańskiej agencji federalnej Centers for Disease Control and Prevention - CDC. Według raportów tej instytucji na terenie USA, liczba epidemii chorób przenoszonych drogą pokarmową (ang. foodborne disease outbreaks) wzrastała systematycznie od początku lat 70. XX wieku, kiedy było ich około $300 \mathrm{w}$ roku $^{3}$. W kolejnych latach liczba ta kształtowała się następująco: 1985 495 epidemii, 1990 - 532, 1995 - 645, 2000 - 1417, 2006 - 1270, 2010 - 852. W ciągu czterech analizowanych dekad (1973 - 2013) nastąpił 3-, 4-krotny wzrost liczby epidemii będących konsekwencją spożycia zatrutej lub skażonej żywności na rynku amerykańskim ${ }^{4}$

Przedstawione przykłady dobitnie ilustrują wzmożony w ostatnich dekadach wzrost incydentów żywnościowych, w tym także wynikających z oszustw i fałszerstw żywnościowych. W przeszłości z podobnym zjawiskiem mieliśmy do czynienia w połowie XIX w. O ile w trakcie pierwszej fali zasadniczą przyczyną była szybko postępująca industrializacja i w następstwie tego powstanie anonimowego konsumenta jako konsekwencja rozluźnienia bezpośrednich kontaktów producent-konsument, o tyle współcześnie przyczyną drugiej fali fałszerstw żywnościowych jest postępująca globalizacja, która zdecydowanie wydłuża łańcuchy dostaw, czyniąc rynek żywności coraz bardziej rozproszonym przestrzennie i jeszcze bardziej anonimowym. Sprawia to, że bezpieczeństwa żywności we współczesnym zglobalizowanym świecie jest szczególnie narażone na ryzyko jego znaczącego obniżenia, a to oznacza dla konsumentów zagrożenie ich zdrowia i zasobów finansowych. Wymaga zatem zdecydowanego przeciwdziałania.

3 Wszystkie dane o liczbie epidemii chorób pokarmowych pochodzą z raportów CDC pt.: Surveillance for Foodborne-Disease Outbreaks - United States, zamieszczonych na stronie http://www.cdc.gov.

$4 \quad$ Szerzej na temat teorii drugiej fali oraz skali współczesnych zagrożeń dla bezpieczeństwa żywności patrz [Kowalczyk 2016]. 


\section{DZIAŁANIA NA RZECZ BEZPIECZEŃSTWA ŻYWNOŚCI}

Sytuacja, jaka powstała, a w zasadzie jej intensyfikacja, która nastąpiła po uwolnieniu procesów globalizacyjnych, wymaga zdecydowanej reakcji dla dobra konsumentów, czyli dla dobra wspólnego. Stanowi bowiem realne zagrożenie dla ich zdrowia, także życia oraz finansów osobistych. Globalizacja generalnie tworzy środowisko niekorzystne dla stanu bezpieczeństwa żywności, co zmusza do przeciwdziałania we wszystkich wymiarach, tj. krajowym, regionalnym oraz globalnym.

Główne kierunki podejmowanych działań winny zmierzać do przeniesienia aktywności w zakresie zwalczania fałszerstw i zanieczyszczeń żywności na poziom ponadkrajowy czyli tam, gdzie przede wszystkim występują te niekorzystne zjawiska. Skuteczne przeciwdziałanie zagrożeniom dla bezpieczeństwa żywności w warunkach globalizacji oraz wolnego mechanizmu rynkowego wymagają zintegrowanych działań ze strony organów krajowych, regionalnych oraz międzynarodowych. Bezpieczeństwo żywności w erze globalizacji wymaga nowego podejścia opartego na założeniu, że nieprawidłowości w globalnym łańcuchu żywnościowym można eliminować wyłącznie, podejmując działania proceduralne, prawne i kontrolne na poziomie globalnym. Współcześnie żaden kraj, nawet najbogatszy, nie może indywidualnie zapewnić bezpieczeństwa żywności obywatelom bez współpracy na płaszczyźnie międzynarodowej z innymi krajami i regionami.

Podejmowane działania należy ukierunkować w dwóch zasadniczych wymiarach: działań „twardych” oraz „miękkich”. Działania twarde są związane z koniecznością tworzenia, zmiany lub modernizacji struktur prawnych, kontrolnych i organizacyjnych w obszarze bezpieczeństwa żywności. Pierwszym i podstawowym obszarem jest prawo żywnościowe. Z kolei działania miękkie odnoszą się do wiedzy o żywności, edukacji konsumenckiej oraz kreowania środowiskowych oraz nadterytorialnych relacji społecznych, a także bieżącego monitorowania oraz informowania o stanie tego bezpieczeństwa i jakości żywności.

\section{PRAWO ŻYWNOŚCIOWE}

Jedną z podstawowych spraw przy tworzeniu systemu bezpieczeństwa żywności jest przyjęcie i wdrożenie skutecznego systemu prawa żywnościowego, w tym efektywnych standardów bezpieczeństwa żywności. Z uwagi na charakter współczesnych zagrożeń dla bezpieczeństwa, zdecydowanie wychodzących poza granice poszczególnych państw oraz błyskawicznie rozprzestrzeniających się po sąsiednich krajach, regionach, a nawet całym globie, potrzebne jest prawo żywnościowe na szczeblu krajowym, regionalnym, a także ogólnoświatowym. By jednak prawo w sposób skuteczny regulowało jakąś dziedzinę życia społecznego czy gospodarczego, niezbędne są: 1) dobra norma prawna, 2) system jej egzekucji. Nawet najlepsza, stworzona z wszelką dostępną wiedzą oraz doświadczeniem norma, bez zapewnienia jej przestrzegania przez stosowne instytucje, pozostaje wyłącznie nic nieznaczącym tekstem.

Szczególnie ważna staje się kwestia zapewnienia egzekucji prawa żywnościowego na szczeblu globalnym, gdyż dorobek norm żywnościowych i standardów jest już całkiem pokaźny. Stanowi go istniejący od 1963 r. Codex Alimentarius. Ale problem tkwi w tym, że jest on fakultatywny, a ponadto, co naturalne w tej sytuacji, nie zawiera przepisów w zakresie egzekucji tychże standardów. Czy możliwa jest zatem zmiana tej sytuacji i wprowadzenie globalnego prawa żywnościowego? W krótkim, a nawet średnim horyzoncie czasowym raczej nie. Wprowadzanie globalnego prawa powinno odbywać się etapowo, a realnie ujmując możliwe tylko z aktywnym udziałem organizacji międzynarodowych, jak 
ONZ (FAO). To, że od strony intelektualnej oraz koncepcyjnej możliwe jest przygotowanie takiego rozwiązania, świadczy raport The Commission on Global Governance, przygotowany przez kilkudziesięciu wybitnych polityków i działaczy z całego świata w 1995 r., pt. Our Global Neighborhood [1995] $]^{5}$, w którym zaproponowano podjęcie próby ustanowienia globalnego zarządzania. Właśnie globalnego zarządzania, a nie globalnego rządu.

Podjęcie wysiłku stworzenia globalnego prawa żywnościowego to działanie niewiele mniej ambitne niż postulaty utworzenia instytucji globalnego zarządzania, zdolnych do ograniczenia samowoli korporacji transnarodowych i negatywnych skutków globalizacji, głoszone od wielu lat przez ekonomistów, a także polityków czy działaczy społecznych, środowiskowych, wreszcie przedstawicieli ruchów konsumenckich. Świat jest podzielony wielowymiarowym zbiorem sprzecznych interesów, celów, zamierzeń oraz planów.

\section{INICJATYWY KONTROLNE NA SZCZEBLU PONADKRAJOWYM}

Poziom bezpieczeństwa żywności w dużym stopniu zależy od skutecznego prawa, a także jego egzekucji. Odnosi się to do sprawności oraz wydolności operacyjnej instytucji powołanych do kontroli żywności. Każdy podmiot działający na rynku spożywczym i paszowym ma świadomość odpowiedzialności administracyjnej i karnej za nieprzestrzeganie przepisów w tym zakresie. Jego postępowanie jest determinowane właśnie obawą przed konsekwencjami łamania prawa. W warunkach globalnej gospodarki i wydłużonych łańcuchów dostaw ta obawa jest redukowana złożonością relacji rynkowych. To może zachęcać do łamania prawa i np. podejmowania działań w zakresie fałszowania żywności. Z tych właśnie powodów niezbędny jest skuteczny system urzędowej kontroli żywności. Działania takie muszą jednak wychodzić poza obszar pojedynczego państwa. Muszą zachodzić tam, gdzie występuje łamanie prawa, czyli w przestrzeni międzynarodowej. Tymczasem struktury kontrolne są narodowe. Nawet Unia Europejska (UE), która jest przykładem zaawansowanej współpracy międzypaństwowej, nie zdecydowała się na powołanie jednolitych struktur. Istniejący od 1979 r. unijny system RASFF (The Rapid Alert System for Food and Feed), czy od 2013 r. AAC (The Administrative Assistance and Cooperation), to w istocie platformy monitorowania określonych zdarzeń, bez uprawnień kontrolnych, a tym bardziej penalizacyjnych. Od 2013 r. Komisja Europejska organizuje kontrole wybranych grup artykułów spożywczych w państwach członkowskich, lecz działania kontrolne zlecane są służbom kontrolnym poszczególnych państw. Nie istnieje bowiem jednolita unijna służba kontrolna. O tym, że działania na szczeblu globalnym są jednak możliwe, przekonuje inicjatywa pod nazwą operacja Opson.

Operacja Opson jest wspólnym przedsięwzięciem realizowanym od 2011 r. przez Interpool oraz Europol we współpracy z zainteresowanymi krajami. Jest przedsięwzięciem ukierunkowanym na dwa obszary: (1) podrabianie żywności i napojów ${ }^{6}$ oraz (2) fałszowanie prowadzące do zaniżania jakości żywności i napojów. W pierwszym roku w operacji Opson I uczestniczyło 11 państw, w tym 10 z UE oraz Demokratyczna Republika Kongo. W operacji Opson III przeprowadzonej w 2013/14 r. było 31 państw, a w ostatniej przeprowadzonej w 2017 r. operacji Opson VI - już 61 państw, w tym 40 spoza UE. W ramach tej operacji skonfiskowano żywność i napoje o wartości 230 mln EUR [Europol 2017].

Warto dodać, że w operacjach Opson od 2013/14 r. uczestniczą także firmy prywatne zainteresowane zwalczaniem fałszerstw żywnościowych. W Opson III firm takich było 16,

Raport Our Global Neighborhood spotkał się krytyką głównie ze strony kół amerykańskich, zaniepokojonych możliwością ograniczenia suwerenności USA w następstwie próby wdrożenia postanowień raportu.

$6 \quad$ W znaczeniu naruszania praw własności intelektualnej innych wytwórców. 
natomiast Opson V (2016) - 21. Były to przykładowo takie firmy i stowarzyszenia, jak: The Coca Cola, Consorzio di tutela Gorgonzola DOP - stowarzyszenie producentów, Unaprol Consorzio Olivicolo Italiano - stowarzyszenie producentów, Danone, Ferrero, Mars, Moët Hennessy, Nestlé, Red Bull, Unilever, Scotch Whisky Association - stowarzyszenie producentów, Tequila Regulatory Council - stowarzyszenie producentów [Interpol/Europol 2016]. W operacjach Opson w latach 2011-2017 nie brała udziału żadna instytucja z Polski, natomiast konfiskowano produkty pochodzące z Polski (podróbka sera edamskiego w Czechach, Opson V). Operacje Opson są znakomitym przykładem współpracy na poziomie międzynarodowym, czyli tam, gdzie zagrożenie bezpieczeństwa żywności jest współcześnie największe. Tylko takie działania są w stanie powstrzymać nieuczciwe firmy, interpretujące wolność gospodarczą w ramach liberalnej gospodarki jako przyzwolenie na łamanie prawa.

\section{KRÓTKIE ŁAŃCUCHY DOSTAW}

Globalizacja przyniosła także istotne wydłużenie łańcuchów dostaw w ramach sektora żywnościowego. Jest to konsekwencja intensyfikacji kontaktów rynkowych oraz zwielokrotnienia transakcji handlowych. W efekcie powstały łańcuchy globalne, czyli łańcuchy o wyjątkowo dużej liczbie ogniw pośrednich pomiędzy producentem surowca - szerzej pierwotnym producentem żywności - a konsumentem. Jako konsekwencja tego zjawiska w zwielokrotnionej postaci wystąpiła tendencja do fałszowania żywności (wydłużenie odległości do konsumenta zwiększa poczucie bezkarności) oraz pogorszenia jej bezpieczeństwa zdrowotnego (wydłużone okresy transportu i składowania, nieprzestrzeganie podstawowych norm sanitarnych, użycie do produkcji skażonych i/lub przeterminowanych - zepsutych składników).

Przeciwdziałaniem temu zjawisku jest skracanie łańcuchów żywnościowych oraz promowanie bezpośrednich relacji producent-konsument. W tych warunkach do nowych form relacji rynkowych należy zaliczyć przykładowo: krótkie łańcuchy żywnościowe (ang. short food supply chains - SFCS) oraz lokalne łańcuchy żywnościowe (ang. local food systems - LFS), a w tym alternatywne sieci żywnościowe (rynki rolnicze), sprzedaż bezpośrednią (ang. farmgate sales), sprzedaż ograniczoną/marginalną oraz wszelkie formy sprzedaży wspierane przez wspólnoty lokalne. Formy te rolnikom i bezpośrednim wytwórcom umożliwiają partycypowanie w większej części wartości dodanej, konsumentom dają możliwość bezpośredniego kontaktu z wytwórcą, co redukuje skłonność tychże do sprzedaży żywności zafałszowanej lub o nieodpowiednim standardzie zdrowotnym.

Te nowe formy rynkowe przynoszą określone korzyści także regionom, w których są rozwijane. Główne z nich to dodatkowe miejsca pracy, transfer umiejętności, rozwój rynku szkoleń oraz doradztwa, poprawa dostępu do żywności wysokiej jakości, wzrost zainteresowania stanem środowiska naturalnego itd. Jest to szansa dla bezpośrednich wytwórców oraz mniejszych firm, które to podmioty nie mają szans na konkurowanie z korporacjami spożywczymi na rynkach globalnych.

\section{EDUKACJA KONSUMENTÓW}

Oprócz działań legislacyjnych oraz instytucjonalnych, poprawa lub utrzymanie stanu bezpieczeństwa żywności w ramach zglobalizowanego wolnego rynku wymaga także działań „miękkich”, ukierunkowanych na konsumenta. W pierwszej kolejności odnosi się to do edukacji konsumentów. Postęp techniczny w zakresie produkcji żywności sprawia bowiem, że na rynku znajduje się coraz więcej produktów nowych technologii, osiągnięć naukowych, 
produktów o zmodyfikowanych właściwościach użytkowych i odżywczych, modyfikacji rzeczywistych i pozornych. Etykiety opakowań stają się coraz obszerniejsze, zawierają coraz więcej informacji. Rozporządzenie unijne nr 1169/2011 w sprawie przekazywania konsumentom informacji na temat żywności, zobowiązuje producentów do zamieszczenia na etykiecie każdego środka spożywczego 12 rodzajów informacji, ponadto dodatkowych 20 informacji na opakowaniach wybranych grup produktów (np. zawierających substancje słodzące lub z dodatkiem fitosteroli, fitostanoli i ich estrów) [Rozporządzenie 1169/2011]. A nie jest to jedyny akt prawny zobowiązujący producentów żywności do obowiązkowego zamieszczania na etykietach konkretnych informacji ${ }^{7}$. Dodatkowo producenci mogą dobrowolnie zamieszczać na etykietach pewne informacje, jak chociażby te o otrzymanych nagrodach i wyróżnieniach czy potwierdzające spełnianie warunków różnych prywatnych i krajowych systemów jakości. A jak wykazał monitoring przeprowadzony na obszarze państw unijnych, takich dobrowolnych systemów jest ponad 900 [Ipsos/London Economics Consortium 2013]. Ogrom tych informacji sprawia, że konsument ma prawo czuć się zagubiony, a to prowadzi do nieporozumień oraz błędnych decyzji.

Wymaga to intensywnej edukacji konsumentów, nie tylko w zakresie dostępnych dla nich informacji o produktach spożywczych, lecz i przestrzegających ich przed najczęściej spotykanymi oszustwami żywnościowymi. Etykiety produktów często zawierają bowiem informacje niejasne dla konsumenta, mogące wprowadzać go w błąd lub sugerować, że produkt ma szczególne właściwości, pomimo że każdy produkt danej grupy asortymentowej ma takie właściwości (np. olej roślinny bez cholesterolu, soki owocowe bez dodatku cukru). Natomiast producenci często nie podają informacji istotnych dla konsumenta, które to mogłyby go zniechęcić do nabycia takiego wyrobu, jak składniki niskiej jakości, dodatki do żywności, surowce GMO itd.

Konsument nieświadomy, bez podstawowej wiedzy na temat produktu jest łatwym obiektem do manipulacji. Podejmuje zatem decyzje oparte na uzyskanym, obarczonym przekłamaniem przekazie, a nie oparte na zdobytej wiedzy. Skutki takich decyzji mogą być - i z reguły są - niebezpieczne i niekorzystne zarówno dla tego konsumenta, jak i uczciwego producenta żywności. Tym samym zyskuje oszust (fałszerz żywności), traci konsument i uczciwy producent.

\section{WZMOCNIENIE RUCHÓW KONSUMENCKICH}

Do ważnych obszarów z zakresu działań na rzecz poprawy stanu bezpieczeństwa żywności należy zaliczyć także wzmocnienie pozycji ruchów konsumenckich. Do swoistych paradoksów należy zaliczyć to, że organizacje z założenia zrzeszające konsumentów należą do słabszych ogniw w większości społeczeństw, tak krajowych, jak regionalnych, na społeczeństwie globalnym kończąc. W niektórych krajach organizacje te są silniejsze, a ich głos należy do opiniotwórczych, lecz co do zasady w większości krajów nie mają one większego wpływu na sytuację gospodarczą, a przede wszystkim rynkową.

Organizacje konsumenckie z założenia mają chronić ludzi przed nadużyciami ze strony firm, w tym głównie nadużyć korporacji w zakresie bezpieczeństwa produktów, nieuczciwych praktyk rynkowych, reklam i oznaczeń wyrobów wprowadzających w błąd itp. Dotyczy to

\footnotetext{
Są nimi także: Rozporządzenie Wykonawcze Komisji (UE) NR 1337/2013 z dnia 13 grudnia 2013 r. ustanawiajace zasady stosowania rozporządzenia (UE) $\mathrm{nr}$ 1169/2011 Parlamentu Europejskiego i Rady w odniesieniu do wskazania kraju pochodzenia lub miejsca pochodzenia świeżego, schłodzonego i zamrożonego mięsa ze świń, z owiec, kóz i drobiu (Dz.Urz. UE L 335 z 14.12.2013), Rozporządzenie Parlamentu Europejskiego i Rady (UE) nr 1151/2012 z dnia 21 listopada 2012 r. w sprawie systemów jakości produktów rolnych i środków spożywczych (Dz.Urz. UE L 343 z 14.12.2012) i wiele innych.
} 
wszystkich grup towarów i usług znajdujących się na rynku. W odniesieniu do rynku żywności jest to jednak szczególnie ważne, bowiem nieprawidłowości czy oszustwa tu występujące mają konsekwencje nie tylko finansowe, lecz co ważniejsze - konsekwencje dla życia i zdrowia ludzi.

Organizacje konsumenckie to naturalny partner instytucji urzędowych kontroli żywności. Zarówno organizacje konsumenckie, jak i instytucje kontrolne występują bowiem w obronie praw konsumentów. Współpraca tych dwóch grup podmiotów jest zatem ze wszech miar pożądana. Wymaga to jednak określonych zachęt do takiej współpracy ze strony organów państwa, a przede wszystkim wzmocnienia organizacji konsumenckich głównie w zakresie poprawy ich aktywności rynkowej, w procesie stanowienia prawa, jego egzekucji oraz rozstrzyganiu sporów rynkowych.

\section{PODSUMOWANIE}

Kryzys globalny początków XXI w. w dużym stopniu ukazał niebezpieczeństwa wynikające ze skrajnie liberalnej gospodarki, zagrożenia dla państw, firm oraz pojedynczych osób. Każe to na nowo zdefiniować podstawowe paradygmaty rozwojowe współczesnej cywilizacji. Problem polega na tym, że te ośrodki, które winny tego dokonać, czyli państwa narodowe, są dzisiaj słabe, a te podmioty, które mają siłę, czyli korporacje transnarodowe, nie są zainteresowane zmianą istniejącej sytuacji, w której właśnie one ustalają główne zasady funkcjonowania poszczególnych rynków z korzyścią dla własnego interesu, a w sytuacjach kryzysowych, jak pokazał to wyraźnie ostatni kryzys, są w stanie wymusić na tychże słabych państwach pokaźne wsparcie finansowe i nie tylko finansowe ${ }^{8}$. W następstwie takich zachowań obecnie, czyli w drugiej dekadzie XXI w., świat znajduje się w sytuacji istotnego zawieszenia pomiędzy kryzysogennym liberalnym system gospodarki globalnej a niezbędnym, lecz nieistniejącym w rzeczywistości nowym paradygmatem rozwojowym. Dotychczasowy paradygmat, jak wskazał Garry Jacobs, opiera się na naiwnej teorii ekonomicznej, zakładającej nieomylność przedsiębiorstwa i wolnego rynku. Tymczasem wolny nieuregulowany rynek nie jest ani wolny, ani uczciwy, ponieważ zawsze działa na korzyść najsilniejszego [Jacobs 2014, s. 11]. Potrzebna jest zatem zmiana i to zarówno sposobu myślenia, jak i sposobu działania światowego społeczeństwa. Tym bardziej że stary paradygmat, a według João Caraça, także globalizacja znalazły się w pułapce, po raz pierwszy w historii bez wyraźnych oznak pokonania tych problemów. Postęp techniczny - główny kreator rozwoju ostatnich stuleci tzw. cywilizacji zachodniej nie rozwiązuje problemów współczesności, a nawet ich przysparza. Państwa nie mają siły ani przyszłości [Caraça 2017]. Nowy paradygmat musi zatem przeciwstawić się dotychczasowym problemom. Wymaga zatem określonego centrum zarządczego, przy czym odnosi się to zarówno do poziomu globalnego (potrzeby budowy instytucji globalnych, ang. global governance), jak i konieczności wzmocnienia siły państw narodowych (w zakresie ich funkcji ustawodawczych i kontrolnych). Musi być zorientowany przede wszystkim na wolność jednostki, a nie wolność firmy i jej Galbraithowskiej technostruktury. Dlatego podstawowym celem powinno być dobro jednostki, człowieka, a nie interes firmy. Należy zdawać sobie sprawę, że wdrożenie takiego paradygmatu nie może być proste, ani oczywiste. Przede wszystkim dlatego, że powiększa on zakres wolności oraz bezpieczeństwa człowieka, kosztem

\footnotetext{
Przykładowo korporacje amerykańskie wymusiły na rządzie Stanów Zjednoczonych wsparcie budżetowe realizowane w różnych formach (subwencji, kredytów, ulg itd.) w latach 2007-2010 na gigantyczną kwotę 16,1 bln USD. Zob. [US GAO 2011].
} 
korporacji i rynku. Jednak musimy pamiętać, że problemy spowodowane przez człowieka moga być rozwiąane tylko przez człowieka [Jacobs 2014, s. 1]. Współczesna struktura gospodarcza i społeczna świata nie powstała sama ani za sprawą niewidzialnej ręki A. Smitha. Spowodował i dał na nią przyzwolenie człowiek. Człowiek może zatem dokonać jej rewizji. Tak dla dobra swojego, jak całego świata.

Dalsza polityka i działania w zakresie ochrony bezpieczeństwa żywności muszą uwzględniać powyższe realia. Globalizacja oraz wolny zliberalizowany rynek tworzą bowiem realne zagrożenia dla tegoż bezpieczeństwa. Takie zjawiska, jak nadmierna eksploatacja zasobów naturalnych, masowy wykup ziemi (ang. land grabbing), przeznaczanie coraz większych obszarów ziem uprawnych na produkcję surowców dla przemysłu, eksplozja zjawiska fałszowania żywności czy eliminacja małych i średnich producentów stanowią o obrazie współczesnego globalnego łańcucha żywnościowego i bezpieczeństwa żywności.

By dokonać zmiany tego stanu niezbędne są przedsięwzięcia oraz inicjatywy zarówno na szczeblu krajowym, jak i globalnym. Współczesne państwo nie ma bowiem dostatecznej realnej władzy, którą mają dzisiaj kapitał i korporacje. By państwu pozostała zatem nie tyle polityka, ile politykowanie, musi nastąpić istotne przewartościowanie systemowego ujęcia struktur wolnego rynku. Głównie w kierunku dodatkowego uregulowania rynków, wzmocnienia roli państw narodowych oraz globalnych standardów żywnościowych. Bezpieczeństwo żywności, a szerzej bezpieczeństwo żywnościowe globu, musi stać się zasadniczym celem przyszłych działań i strategii państw oraz instytucji międzynarodowych, a także samych korporacji. W przypadku tych ostatnich także w dobrze pojętym ich interesie własnym.

\section{LITERATURA}

Accum Frederick, 1820: Treatise on adulterations of food and culinary poisons, exhibiting the fraudulent sophistications of bread, beer, wine, spirituous liquors, tea, coffee, cream, confectionery, vinegar, mustard, pepper, cheese, olive oil, pickles, and other articles employed in domestic economy, and methods of detecting them, Printed by J. Mallett, London (Soho), 1820.

Caraça João, 2017: Globalisation Trapped, „CADMUS Journal”, 3(2), May. http://www.cadmusjournal. org/article/volume-3/issue-2/globalisation-trapped.

Cendrowski Harry, W. Louis Petro, 2007: History of Fraud Deterrence, [w] The Handbook of fraud deterrence, ed. H. Cendrowski, J.P. Martin, L.W. Petro, John Wiley \& Sons, Inc., New Jersey.

Chang Ha-Joon, 2016: Źli Samarytanie. Mit wolnego handlu i tajna historia kapitalizmu, Wydawnictwo Krytyki Politycznej, Warszawa.

Dodge v. Ford Motor Co., 1919: 170 N.W. 668 (Mich. 1919). https://pages.law.illinois.edu/aviram/ Dodge.pdf, dostęp: 01.09.2017.

Europol, 2017: EUR 230 Million Worth of Fake Food and Beverages Seized in Global Opson Operation Targeting Food Fraud, "Press Release", 25 April. https://www.europol.europa.eu/newsroom/news/ eur-230-million-worth-of-fake-food-and-beverages-seized-in-global-opson-operation-targetingfood-fraud.

Food Standards Agency, 2014: Annual Report of Incidents 2013, June. https://www.food.gov.uk/ annual-report-incidents-2013.pdf.

Gersbach Hans, Armin Schmutzler, 2000: Declining costs of communication and transportation: What are the effects on agglomerations? "European Economic Review", 44(9), October.

Hassall Artur Hill, 1855: Food and its adulterations; Comprising the reports of the analytical sanitary commission of „The Lancet” for the years 1851 to 1854 inclusive, revised and extended: being records of the results of some thousands of original microscopical and chemical analyses of the solids and fluids consumed by all classes of the public; and containing the names and addresses of the various merchants, manufacturers, and tradesmen of whom the analysed articles were purchased, Longman, Brown, Green, and Longmans, London.

Interpol/Europol, 2016: Report: Operation OPSON V, O29 - FP copy//INTERPOL IGGH, October. https://www.europol.europa.eu/report_opson_v.pdf. 
Ipsos/London Economics Consortium, 2013: Consumer market Study on the functioning of voluntary food labelling schemes for consumers in the European Union, EAHC/FWC/2012 86 04, Final report by the Ipsos and London Economics Consortium, December.

Jacobs Garry, 2014: New Paradigm: The Necessity and the Opportunity, “CADMUS Journal”, 2(2), http:// cadmusjournal.org/files/pdfreprints/vol2issue2/reprint2-i2-new-paradigm-the-necessity-gjacobs.pdf.

Kowalczyk Stanisław, 2016: Bezpieczeństwo i jakość żywności, Wydawnictwo Naukowe PWN, Warszawa.

Kowalczyk Stanisław, 2010: Globalizacja agrobiznesu: specyfika, wymiary, konsekwencje, „Zagadnienia Ekonomiki Rolnej”, nr 2.

Krugman Paul, 1991: Increasing Returns and Economic Geography, "The Journal of Political Economy", 99(3).

Mitchell John, 1848: Treatise on the falsifications of food, and the chemical means employed to detect them. Containing water, flour, bread, milk, cream, beer, cider, wines, spirituous liquors, coffee, tea, chocolate, sugar, honey, lozenges, cheese, vinegar, pickles, anchovy sauce and paste, catsup, olive (salad) oil, pepper, mustard, Hippolyte Baillière, Publisher, London.

Normandy Alphonse, 1850: The commercial hand-book of chemical analysis; or, practical instructions for the determination of the intrinsic or commercial value of substances used in manufactures in trades and in the arts, Published by George Knight \& Sons, London.

Our Global Neighborhood, 1995: The Report of the Commission on Global Governance. http://www. gdrc.org/u-gov/global-neighbourhood/.

Rozporzadzenie Parlamentu Europejskiego i Rady (UE) Nr 1169/2011 z dnia 25 października 2011 r. $w$ sprawie przekazywania konsumentom informacji na temat żywności, zmiany rozporządzeń Parlamentu Europejskiego i Rady (WE) nr 1924/2006 i (WE) nr 1925/2006 oraz uchylenia dyrektywy Komisji 87/250/EWG, dyrektywy Rady 90/496/EWG, dyrektywy Komisji 1999/10/WE, dyrektywy 2000/13/WE Parlamentu Europejskiego i Rady, dyrektyw Komisji 2002/67/WE i 2008/5/WE oraz rozporzadzenia Komisji (WE) nr 608/2004, Dz.Urz. UE L 304 z 22.11.2011.

Smith Adam, 1776: An Inquiry into the Nature and Causes of the Wealth of Nations, W. Strahan and T. Cadell, In The Strand, London. http://files.libertyfund.org/files/220/0141-02 Bk.pdf.

The International Bank for Reconstruction and Development/The World Bank, 2009: World Development Report 2009, Reshaping Economic Geography, Washington.

The Geography of Transport Systems, 2017: Transport and Communications Costs Indexes, 1920-2015. https://people.hofstra.edu/geotrans/about.html.

US GAO, 2011: Opportunities Exist to Strengthen Policies and Processes for Managing Emergency Assistance, Federal Reserve System, Report to Congressional Addressees, GAO-11-696, http:// www.gao.gov/assets/330/321506.pdf.

WTO, 2017: World Trade Statistical Review 2017, Geneva.

\title{
Stanisław Kowalczyk \\ FREE MARKET AND THE FOOD SAFETY IN THE GLOBALIZATION ERA
}

\begin{abstract}
Summary
The study attempts to identify potential threats to food safety resulting from the globalization process and the directly related extreme liberalization of economic relations at the international level as well as indication of the necessary remedial actions in the field of food safety protection. The analysis covered the contemporary status of food safety and the scale of occurring food fraud in the world. The remedial actions include the establishment of a global food law, undertaking food control initiatives at the supranational level, the promotion of short supply chains, and finally the consumer education and strengthening of consumer movements.
\end{abstract}

Adres do korespondencji:

Dr hab. Stanisław Kowalczyk, prof. SGH

Szkoła Główna Handlowa w Warszawie Instytut Rynków i Konkurencji

al. Niepodległości 162, 02-554 Warszawa e-mail: skowal1@sgh.waw.pl 